\title{
The Effect of Familiarity and Brand Attitude of Mobile Character Products on Consumers' Purchasing Behavior
}

\section{- Focusing on Kakao Friends Characters -}

\author{
Ji-Hoi Choi1), Myoun Kim²)
}

\begin{abstract}
At the present time due to development of technology and diversity of consumer preference, companies are producing a wide variety of products. Under these circumstances, the companies' products have been marketing of using the characters which are familiar to consumers. The purpose of this study is to find out whether intimacy of the product character, product loyalty, and brand attitude can affect the consumer purchasing behavior positively. This study was carried out researching the domestic and foreign documents and based on the empirical analysis. A sample study of 232 people was conducted by measurement target including college students and office workers who are interested in the characters. Based from the results of the study, product loyalty and brand attitude affected consumer purchasing behavior whereas intimacy of the character has no effect at all. Namely consumers can feel the intimacy of characters but they are not interested in the products containning the characters. Factors that have the greatest impact on the purchase of a mobile character appeared as brand attitude.
\end{abstract}

Keywords : Character, Product Loyalty, Brand Attitude, Purchasing Behavior

\section{Introduction}

The character industry is fundamentally aimed at merchandising. Until a character is commercialized as a brand, a thorough strategy from marketing to distribution is necessary for basic design and story contents development. The strength of the character industry is to maximize added value through the ripple effect of the brand. In the past, it made up the biggest part of informing the characters through broadcasting and movies. But now, with the

Received(August 17, 2018), Review Result(1st: September 3, 2018, 2nd: October 15, 2018), Accepted(December 10, 2018)

1) (Adjunct professor) 10843 Department of Business Administration, Seyeong University, 170 Seoyeong-ro Wollong-myeon, Paju-si, Gyeongi-do, Republic of Korea

email: cjh220@hanmail.net

2) (Professor, Corresponding Author) 03063 Department of Design, School of Art, Sungkyunkwan University, 25-2 Sungkyunkwan-ro, Jongno-gu, Seoul, Republic of Korea

email: starmyoun@naver.com 


\section{The Effect of Familiarity and Brand Attitude of Mobile Character Products an Consumers' Purchasing Behavior}

- Focusing on Kakao Friends Characters -

development of the internet, it is possible to convey to the consumers interestingly through the online promotion which can appeal the characters easily and rapidly as well as the convenience of the character development etc(Joe and Choi, 2003)[1]. In addition, due to the attractiveness of the characters, the character-related industry has grown, and some companies are investing heavily in developing characters or popularizing certain characters through mass media. Because characters are expressed in a unique way, they can be used in many areas such as clothing and accessories, food, stationery, electronic games, learning materials, and music publishing, etc(Baek and Yoo, 2002)[2].

In particular, it can be distinguished from other company's products by giving friendliness to consumers and character can be highlighted as a key element to form a specific image for a company or brand through its own characteristics. Especially, because every consumer feels and thinks about characters differently, the profound understanding of their psychological and symbolic attributes in marketing strategies of character goods will contribute to corporate performance. In order to do this, it is most important to grasp the purchasing behavior of the consumers, and it is the best indicator for predicting the purchasing behavior by understanding the purchasing intention of the consumer because the consumers show a wide range of different purchasing behaviors according to their own personality as well as situations(Kwon, 2001)[3]. The popularity of smartphones has led to the emergence of messenger characters such as "Kakao Friend" as the main communication means of mobile messenger as a new popular character. The reasons for selecting Kakao Friends in this study are that Kakao is a leader in the Korean mobile messenger market and has popularity for many years, overtaking Korea's top-ranking characters and ranking first in favor of characters[4].

\section{Literature Review}

\subsection{Kakao Firends Character}

A character is regarded as a special type of brand symbol, and various characteristics such as name, personality, action, and voice as well as appearance characteristics are included in the product or service, thereby helping to form an intimacy with the customer[5]. A mobile character is a character used in a smart device.

Kakao Friends are seven characters released by Kakao corporation in November 2012. The characters are created by a designer, Kwon Sun-ho, nicknamed as 'Hozo', and three emoticon 
designers. 'Tube', a timid and soft - hearted duck, 'Apeach', a rash and drastic peach, 'Cone' an unidentified crocodile, 'Muzi', wearing a rabbit costume, 'Frodo', a wealthy city dog, 'Neo', a cat, and 'Jay-G' a lonely and tender mole are they. The six characters, all have interesting stories. First, Tube, a timid and soft - hearted duck turns into a crazy one when he feels extreme fear. Second, mischievous Apeach undergoes puberty, who has escaped from a peach tree knowing that it has become monoecious by gene manipulation. Third, Con looks like a small crocodile that has raised Muzi and always has a secret, showing a side face only. Fourth, Muzi is a yellow radish wearing a rabbit costume, who is curious and mischievous. Frodo is a hybrid, and it's his big complex. Sixth, Neo is a sassy and mean cat with a bob wig and Frodo's girlfriend. The seventh, Jay- $G$, is an underground agent dispatched to the ground to seek rabbit's liber and so, trailing behind Muzi(Wikipedia, 2015)[6]. The storytelling setup of the characters is planned from the development stage, and they are meant to be used as a means of communication that can be enjoyed through messenger.

\subsection{Product Preference}

Kleins and Baker(2004)[7] defined the preference as a behavioral reaction, a psychological process, with a prejudice that appears over time by several decision units in relation to one or more alternatives. Joy and Sherry(2003)[8] viewed it as the degree of repetitive purchasing of a specific brand and the favorable attitude toward it. And he said that the consumers with high brand preference purchase products of the brand repeatedly and show stronger loyalty than to other brands. Jones and Sassers(1995)[9] said that the consumer with product preference means that they repurchase particular brand's products for a long period of time, recommend them to others And a commitment to a particular brand, and furthermore are willing to pay more.

In this study, products are mobile character of Kakao Friends, product preference will be defined as the frequent repurchase with value including the quality experience with the product drawing consumers' attention based on the formation of a positive and preferable image.

\subsection{Product Familiarity}

Character culture is becoming a trend, and the character marketing trend in the food industry aiming at children and adults is strong. No only Disney, Hello Cacao Friends, Cacao Friends, Line Friends, and other cartoon and movie characters but social network service(SNS) characters 


\section{The Effect of Familiarity and Brand Attitude of Mobile Character Products an Consumers' Purchasing Behavior}

- Focusing an Kakao Friends Characters -

are going into the market. With this, companies are increasing the positive image of the brand and the brand familiarity to consumers. Keller (2003)[10] defined brand familiarity as a force reminiscent of a brand name as determined by the power associated with the brand name in memory. They reported that intention to purchase is higher in the more familiar brand. Also exposure to persuasive communication or repetition of familiar stimulus arouses positive cognitive responses of consumers rather than repetition of unfamiliar message. Song and $\operatorname{Nam}(2006)[11]$ suggested that the effect of the brand power of familiar brands was found to be more positive than that of unfamiliar brands because consumers pay selective attention to the familiar brand in the information processing process and interpret it more preferably. In this way, the development and utilization of products using character design make consumers have a positive image of the brand so that buyers can trust the brand and pay more than the competitive products.

\subsection{Brand Attitude}

Suh and $\operatorname{Kim}(2003)[12]$ found that brand attitudes mean a degree of disliking or liking a particular brand. It can also be defined as an idea of a positive or negative feeling or a favorable or unfavorable attitude that an individual has to a particular brand. In addition, brand attitudes have been used to understand and predict consumer purchasing behaviors such as brand choice because they tend to be stable and persistent. Cohen and Reed[13] argue that brand attitudes are related to beliefs about functional and empirical benefits and also to the symbolic concept of expressing self through brand. Assael(1992)[14] also emphasized the importance of brand preference in that consumer satisfaction to a certain brand product leads to the brand preference, which means repurchase will occur eventually.

\subsection{Consumer Purchasing behavior}

Purchasing behavior is defined as purchasing products through a process of searching for information, evaluating and selecting products when consumers' perceiving products needed according to motives such as social and cultural environmental factors and personal desires(Chung and Cho, 2014)[15].

Richardson (1996)[16] noted that consumers perceive the products they need by motivating them, such as personal needs and environmental factors, and show basic purchasing patterns to evaluate and select products through the process of information seeking. In other words, 
consumers are aware of the necessity and importance of the product in the process of purchasing behavior and measure whether they are willing to purchase it. Kim and Sohn(2010)[17] define it as the psychological attitude toward the willingness to purchase a specific brand through the overall evaluation such as the desire to purchase, the intention to recommend, and availability. Consumer behavior as decision process is influenced by internal and external factors as well as individual preference and social and cultural trend, which is related to individuals' psychological factors to decide to purchase a specific product. Based on these discussions, this study aims to investigate factors affecting consumer purchasing behaviors when purchasing mobile character products.

\section{Research Design}

\subsection{Research Model}

In this study, a research model presented in [Fig. 1] is to analyze the effects of product preference, product familiarity, and brand attitude on the consumer purchasing behavior of mobile products.

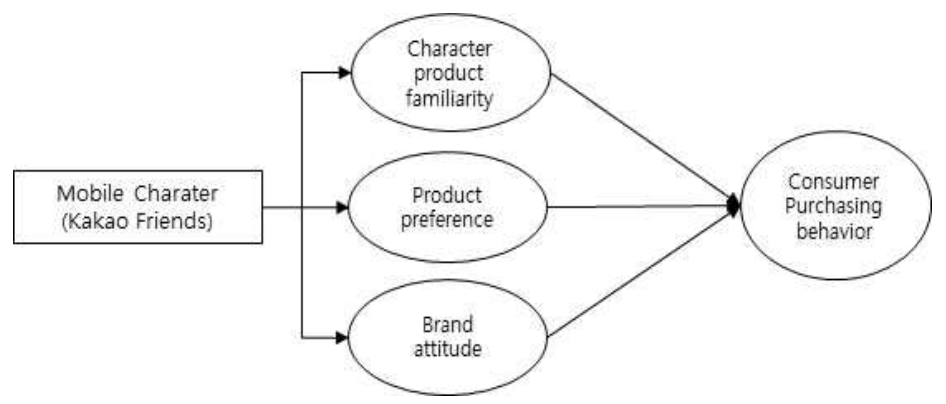

[Fig. 1] Research Model

\subsection{Sampling and Data Collection}

This study was conducted by Judgment Sampling, one of the Non-Probability Sampling methods. Judgment Sampling is a method of selecting a particular group that is well aware of the research problem or is likely to reflect the opinion of the population(Ahn and Lim, 2000)[18]. In the case of people who know the character or who have purchased the character 
The Effect of Familiarity and Brand Attitude of Mobile Character Products on Consumers' Purchasing Behavior

- Focusing an Kakao Friends Characters -

goods as in this study, it is judged that it is easy to evaluate the survey and the judgment sampling method is used. In addition, this study selected the subjects who had experience purchasing the character goods made using the character 'Cacao Friends'. The survey was conducted over three months from September 07 to November 30, 2015, and a total of 300 copies were distributed to collect 274 (91.3\%) copies. Of these, 42 (15.3\%) were unfairly answered, so $232(84.7 \%)$ samples that were valid in terms of reliability were finally used for analysis.

\subsection{Research Process and Analysis Method}

This study conducted preliminary surveys and the main survey. The preliminary survey was conducted to increase the understanding of the questionnaires and to increase the responsiveness of the questionnaire. Face to face interview was done for 10 days from September 10 to September 20, 2015. In addition to the metrics presented in the previous research, the interviews were conducted on related industry workers and character goods purchasers to determine whether newly developed measurement items were appropriate or additional items to be presented. The questionnaire was supplemented and revised through this process. Data collected through this study were analyzed using the SPSS 18.0 statistical program. The general characteristics of the survey subjects were analyzed using frequency analysis, and the reliability of the collected data was verified by Cronbach 's Alpha coefficient. Confirmatory Factor Analysis (CFA) was conducted to ensure internal validity of discriminant validity and convergent validity. Finally, the relationship between the factors affecting activation was tested by regression analysis.

\section{Empirical Analysis}

\subsection{Characteristics of Subjects}

The subjects of this study were 82 men (35.3\%) and 150 women (64.7\%). The percentage of women was more than $30 \%$. In terms of the distribution of education, university graduation was the highest at $83.2 \%$, followed by college graduation at $10.3 \%$. The occupation of the subjects was the highest at $86.2 \%$ for students, followed by office workers $(5.6 \%)$. 


\subsection{Reliability and Validity Analysis of Measured Variables}

Prior to the hypothesis testing, the reliability and validity of the data used in this study were verified. Cronbach's Alpha coefficients for the items were measured and the reliability was measured. Convergent validity and discriminant validity of the items were confirmed by statistical factor analysis. Factor analysis was performed by principal component analysis. To clarify the classification of the factors, the rotation of the factors was done by varimax rotation. The extraction of factor numbers has been specified to extract factors with eigen values greater than 1.

In general, the conceptual validity between the constituent concepts is secured by satisfying the conditions of the cumulative dispersion ratio and the factor loading amount. In the social sciences, factors that account for about $60 \%$ of the total variance are selected and that factor loading is more than $0.4 \%$. The conceptual validity of constructive concepts was found to be sufficient (Bagozzi, RP and Yi, 1998[19]; Challagalla, GN and Shervani, 1996[20]; Singh, J. and Rhoads, 1991[21]). The Cronbach's Alpha coefficient of 0.6 or higher is considered to be reliable (Nunnally, 1994)[22], and the reliability of the items used in this study was found to be satisfactory.

[Table 1] Factor Analysis Results on Measurement Variables

\begin{tabular}{|l|c|c|c|c|}
\hline Measuring items & \multicolumn{4}{l|}{ Factors } \\
\hline Measuring items & Preference & Familiarity & Attitude & Behavior \\
\hline I have favorite character products. & .269 & .632 & .296 & -.206 \\
\hline I know this character product. & .216 & .628 & .002 & -.055 \\
\hline I feel familiar with this character product. & .044 & .776 & .096 & .166 \\
\hline $\begin{array}{l}\text { I feel familiar with products related to this character } \\
\text { images. }\end{array}$ & .116 & .736 & .194 & .269 \\
\hline I will keep using this character product. & .216 & .257 & .843 & .113 \\
\hline $\begin{array}{l}\text { I tend to talk positively on the character products that } \\
\text { I use. }\end{array}$ & .195 & .089 & .891 & .144 \\
\hline I like this character brand. & & & & \\
\hline I feel positive about this character brand. & .723 & .245 & .067 & .307 \\
\hline $\begin{array}{l}\text { I like this character brand than any other character } \\
\text { brand. }\end{array}$ & .820 & .125 & .216 & .155 \\
\hline I am positive on this character brand. & .830 & .218 & .118 & .147 \\
\hline I like to buy products with this character. & .331 & .135 & -.001 & .784 \\
\hline $\begin{array}{l}\text { I like to recommend products with this character to } \\
\text { others. }\end{array}$ & .121 & .028 & .240 & .870 \\
\hline
\end{tabular}


The Effect of Familiarity and Brand Attitude of Mobile Character Products an Consumers' Purchasing Behavior

- Focusing an Kakao Friends Characters -

\subsection{Evaluation of Research Model}

In this study, empirical analysis was conducted to determine the factors that consumers purchase character products as familiarity, product loyalty, and brand attitude of character products.

In order to see whether the three variables set in the survey design affect the consumer purchasing behavior, the multiple regression analysis as shown in [Table 2] showed the following significant probabilities. The familiarity of character products was not significant ( $P$ $<0.05)$ compared to other variables. The influence part ( $t$ value) also showed little significance in product familiarity. In terms of brand attitudes $(t=5.050)$ and product preference $(t=$ 2.319), they seem to be influential but not insignificant. In summary, the familiarity of character products has no effect on consumer purchasing behavior while product preference and brand attitude are influential. In addition, the magnitude of influence also influences brand attitude more than product preference.

[Table 2] Familiarity of The Character Goods, Products, Loyalty, and Brand Attitudes and Influence Consumer Purchasing Behavior

\begin{tabular}{|c|c|c|c|c|}
\hline Variable & $\mathrm{B}$ & Beta & $\mathrm{t}$ & $\mathrm{p}$ \\
\hline (Constant) & 2.466 & & 3.171 & .002 \\
Character Product Familiarity & .023 & .029 & .434 & .665 \\
Product Preference & .184 & .157 & 2.319 & .021 \\
Brand Attitude & .203 & .344 & 5.050 & .000 \\
\hline R square $=.201 \quad \mathrm{df} 1=3 \quad \mathrm{df} 2=228 \quad \mathrm{~F}=19.133$ & signif $\mathrm{F}=.000$ \\
\hline
\end{tabular}

\section{Conclusion}

This study examined the effects of characters on consumer's purchasing behavior. As a result, it was found that product preference and brand attitude had a weak influence on consumer purchasing behavior. These results suggest some implication for the following research.

First, companies offering products using characters should increase their interest in brand development using characters. In other words, consumers have an affinity for and trust in brands that use their characters, and they see that the brand is differentiated from other brands. Therefore, companies need strategic marketing to enable consumers to perceive character brand. Therefore, companies need strategic marketing that can influence to form consumers' perception on character brand.

Second, there is a need to improve the familiarity of character products. In other words, 
although consumers are familiar with characters, they are less interested in products including characters, so it is necessary to find ways to engage consumers with their own charms.

Third, the relationship between the character and the product should be considered when developing the character product. In other words, consumers have a lot of desire to know how and why character products are made. Therefore, if companies make good use of these points and take advantage benefits of the products and characters, they will be able to increase the purchase intention of the consumers.

This study has the following limitations. Therefore, the researcher presents the following research directions. First, although empirical studies were conducted based on frequently advertised and highly accessible characters, it was difficult to generalize the evaluation of the familiarity of character products. In the future, it is necessary to study the character products that are closely made with the form of characters. Second, we could not develop a new scale. In other words, the researcher suggested only familiarity, product preference, and brand attitude as factors affecting consumer's behavior. However, there are likely to be other variables. Therefore, various variables should be studied in the future. Third, we looked at consumer purchasing behavior centered on products with characters, but it is necessary to consider products that represent the characters themselves in future studies.

In conclusion, we hope that this study will be used as important data for character product research, and character makers are expected to develop diverse characters and products that can meet consumers' needs with more new contents.

\section{References}

[1] Hye Jin Joe and Suk Joon Choi, Research Reports : The research of marketing strategies for character brand, The Korea Society of Design Culture, (2003), Vol.9, No.3, pp.99-111.

[2] Kyung Sil Baek and Tai Soon Yoo, Transactions : An Analysis of Consumer Preference and Purchasing Behavior for the Character Image Used in Fashion Commodity, Journal of the Korean Society of Clothing and Textiles, (2002), Vol.26, No.5, pp.561-572.

[3] Ick Hyun Kwon, Effect of Advertising Message Framing, Journal of Consumer Studies, (2001), Vol.12, No.4, pp.209-222.

[4] http://www.yonhapnews.co.kr/bulletin/2017/04/18/0200000000 AKR20170418172300033.HTML(2017.10.1.), April 19 (2017)

[5] K. L. Keller, Strategic Brand Management Building, Measuring and Management, Brand Equity, Prentice Hall, (1998), pp.146. 


\section{The Effect of Familiarity and Brand Attitude of Mobile Character Products an Consumers' Purchasing Behavior \\ - Focusing an Kakao Friends Characters -}

[6] Kakao Friends, http://ko.wikipedia.org, June 14 (2015)

[7] S. S. Kleine and S. M. Baker, An Integrative Review of Material Possession Attachment. Academy of Marketing Science Review, (2004), Vol.1, No.1, pp.1-2.

[8] A. Joy and J. F. Sherry, Speaking of Art as Embodied Imagination, Journal of Consumer Research, (2003), Vol.30, No.2, pp.259-262.

[9] T. O. Jones and W. E. Sasser, Why satisfied customers defect, Harvard Business Review, (1995), pp.88-99.

[10] K. L. Keller, Strategic Brand Management : Building, Managing Brand Equity 2nd ed., Upper Saddle River, NJ: Prentice-Hall, (2003).

[11] Kyun Seok Song and Yoon Hyung Nam, The Effects of Brand Equity Components on the Brand Familiarity, Journal of Product Research, (2006), Vol.24, No.2, pp.123-149.

[12] Mun Shik Suh, and Yu Kyung Kim, A Study on the Effect of Sense of Community on the Brand Community Identification and Brand Attitude in Online Brand Community, Journal of Marketing Management Research, (2003), Vol.8 No.2, pp.49-77.

[13] J. B. Cohen and A. Reed, A multiple path way anchoring and adjustment model of attitude generation and recruitment, Journal of Consumer Research, (2006), Vol.33, No.1, pp.1-15.

[14] H. Assael, Consumer Behavior and Marketing Action, 4nd Boston, Massachusetts, Kent publishing Company, (1992), pp.100-112.

[15] Da Un Chung and Yu Jin Cho, Accessories Purchasing behavior according to Male Consumer Life Style, KOREA SCIENCE \& ART FORUM, (2014), Vol.14, pp.625-641.

[16] V. Richardson, The role of attitudes and beliefs in learning to teach. In J. Sikula (Ed.), Handbook of research on teacher education 2nd ed., New York: Macmillan, (1996), pp.102-119.

[17] Hyo Kyung Kim and Soo Jin Sohn, The Effect of Utilizing StarMarketing on Ad Attitude, Brand Attitude and Purchasing Intentions - in the DaeMyung Resort Vivaldi Park, Korea Academic Society Tourism Management, (2010), Vol.25 No.2, pp.229-251.

[18] Kwang Ho Ahn and Byung Hoon Lim, Principles of Marketing Research, bobmunsa, (2000)

[19] R. P. Bagozzi and Y. Yi, On the Evaluation of Structural equation Models, Journal of the Academy of Marketing Science, (1998), Vol.16, No.1, pp.74-94.

[20] G. N. Challagalla and T. A. Shervani, Dimension and Type of Supervisory Control: Effects on Salesperson Performance and Satisfaction, Journal of Marketing, 60(January), (1996), Vol.60, Issue 1, pp.89-105.

[21] J. Singh and G. K. Rhoads, Boundary Role Ambiguity in Marketing Oriented Positions: A Multidimensional, Multifaceted Operationalization, Journal of Marketing Research, (1991), Vol.28, No.3, pp.328-338.

[22] J. C. Nunnally, Psychometric Theory, New York, McGraw-Hill; 3rd edition (1994). 